\title{
Knowledge, Attitude, and Practice of Paracetamol and Ibuprofen Administration Among Caregivers of the Pediatric Age Group in Jeddah
}

Fatemah Kamel ${ }^{1}$, Rania Magadmi ${ }^{1}$, Noran M. AbuOuf ${ }^{2}$, Faisal S. Alqahtani ${ }^{3}$, Abdullah A. Bamousa ${ }^{2}$, Abdulrahman T. Alqutub ${ }^{4}$, Abdulrahman A. Bagber ${ }^{2}$, Albraa H. Abdulgafor ${ }^{2}$, Fayez Alzahrani ${ }^{2}$, Hassan Alsafi $^{2}$

1. Pharmacology, King Abdulaziz University, Jeddah, SAU 2. Pediatrics, King Abdulaziz University, Jeddah, SAU 3. Medicine, King Abdulaziz University, Jeddah, SAU 4. Medicine and Surgery, King Abdulaziz University, Jeddah, SAU

Corresponding author: Abdullah A. Bamousa, abamousa97@gmail.com

\section{Abstract \\ Background}

Fever is one of the most common pediatric conditions usually managed by parents and the cause of nearly all pediatrician visits. However, many parents find the management of childhood fever and febrile diseases challenging owing to a lack of understanding of the nature, effects, and therapies of fever management.

\section{Objectives}

This study aimed to assess the knowledge, attitude, and practice of paracetamol and ibuprofen administration among caregivers of the pediatric age group.

\section{Design}

Observational cross-sectional survey.

\section{Setting}

Jeddah, Saudi Arabia.

\section{Materials and Methods}

Data were collected between April 2018 and April 2019 using a pretested interviewer-administered questionnaire consisting of 40 questions.

\section{Sample Size}

Overall, 493 caregivers were interviewed.

Review began $12 / 23 / 2020$ Review ended 01/03/2021 Published 01/03/2021

\section{(๑) Copyright 2021}

Kamel et al. This is an open access article distributed under the terms of the Creative Commons Attribution License CC-BY 4.0., which permits unrestricted use, distribution, and reproduction in any medium, provided the original author and source are credited.

\section{Results}

Paracetamol was reported as the most common antipyretic used by the caregivers (54\%) to control fever. Ibuprofen was the least preferred drug (18.5\%). The majority of the participants (51.7\%) admitted administering antipyretics at a body temperature of $38-38.5^{\circ} \mathrm{C}$. A total of $90.7 \%$ of the participants measured children's temperature using a thermometer before administering antipyretics. Dosage was determined according to each child's age (40.4\%), weight (32\%), or illness severity (27.6\%). However, 36.7\% and $51.5 \%$ of the participants were unsure of the correct dosage of paracetamol and ibuprofen, respectively. Regarding the maximum frequency of paracetamol use, only $3.7 \%$ of the participants answered correctly. Most parents (70.4\%) believed that a paracetamol/ibuprofen prescription was not necessary. Overall, $97 \%$ of the sample demonstrated inadequate knowledge about antipyretic administration.

\section{Conclusions}

Most caregivers had inadequate knowledge regarding factors that influence paracetamol and ibuprofen dosage and frequency of administration. This low level of knowledge increases the risk of improper drug intake, which can result in serious side effects, thereby indicating the need for the development of educational route programs to provide parents with appropriate education and information on fever and fever management.

Categories: Pediatrics, Other

Keywords: pain, fever management, pediatric pharmacology 


\section{Introduction}

Fever is one of the most common pediatric conditions managed by parents and the cause of nearly $70 \%$ of all pediatrician visits [1]. However, although fever is a common occurrence, the management of childhood fever remains challenging for many parents $[2,3]$. This is because fever is not well understood by the general population; consequently, many parents find fever management overwhelming and intimidating, resulting in anxiety and concern [4-6]. According to various studies in published literature, parents have excessive conflicting information as well as misconceptions on fever management [1-4]. Moreover, many parents perceive pediatric fever as a disease rather than a sign or symptom of illness and therefore have several misconceptions about its management. Moreover, insufficient knowledge of the fever's cause, coupled with misconceptions about its effects on a child's health, results in excessive parental fear and anxiety regarding this condition [1].

Paracetamol, also known as acetaminophen, is an antipyretic commonly used for the management of fever and moderate to mild pain in all age groups, and it is well documented to be safe when used at the recommended doses; in many countries, it is often sold as an over-the-counter painkiller. The effectiveness of paracetamol is identical to that of aspirin; however, unlike aspirin, its anti-inflammatory activity is demonstrable. Paracetamol is also preferred over aspirin because it is less likely to irritate the stomach [7]. Furthermore, after its discovery, paracetamol use became more prevalent as it was considered a viable replacement for aspirin, especially in pediatric patients with a high risk of developing Reye syndrome as a side effect of aspirin use [8]. This makes paracetamol the first-choice medicine to treat and reduce fever in children, with most parents having used the drug since their child's first febrile illness. Paracetamol is also the most commonly used drug for self-medication by mothers of children $\leqslant 12$ years of age [7].

Although paracetamol has been widely used for fever and pain management for more than 60-70 years, over-toxicity cases have been reported [7]. It has been found that paracetamol is one of the over-the-counter medications commonly associated with unintentional overdose in children under the age of five years [9]. Paracetamol overdose has also been associated with life-threatening hepatic damage due to the excessive production of the reactive and toxic metabolite $\mathrm{N}$-acetyl-p-benzoquinone imine during drug metabolism [10]. Hepatic damage is dangerous because it often passes unnoticed, especially during the first four to six days of occurrence [7]. Most severe pediatric hepatotoxicity cases were attributed primarily to cumulative toxicity resulting from repetitive doses rather than acute intoxication caused by a single massive overdose [11]. This implies that administering paracetamol at the correct dosage and time interval can substantially reduce the potential effect for hepatic damage.

A study has shown that paracetamol poisoning is one of the most common causes of acute liver failure in the United States and the United Kingdom [12]. In countries where paracetamol is widely used, several cases of acute damage to liver cells due to repeated doses of paracetamol have been reported, especially if the maximum therapeutic dose of $90 \mathrm{mg} / \mathrm{kg} / 24 \mathrm{~h}$ is exceeded [12].

Ibuprofen is a non-steroidal anti-inflammatory drug [13] that reduces the activity of hormones associated with pain and inflammation in the body. It is commonly used to reduce fever and treat inflammation or pain caused by different conditions, including toothache, headache, arthritis, back pain, or minor injury. Ibuprofen overdoses lead to effects similar to those caused by paracetamol since both are painkillers [14]. Further, ibuprofen overdose has been associated with gastrointestinal tract (GIT) complications, acute renal failure, and metabolic acidosis. The severity of these side effects indicates that caregivers need to be knowledgeable about administering these antipyretics to children. Thus, here, we aimed to assess the knowledge, awareness, and practice of ibuprofen and paracetamol administration by caregivers and draw conclusions on how to implement a public awareness program for antipyretic use in pediatric patients.

\section{Materials And Methods}

\section{Ethics approval}

The study was approved by the Unit of Biomedical Ethics Research Committee at the Faculty of Medicine, King Abdulaziz University (Reference No. 75-20). Informed consent was obtained from all participants before the commencement of the interviews.

\section{Study setting}

This observational cross-sectional study included caregivers of children living in the city of Jeddah, in the western region of Saudi Arabia. Data were collected between April 2018 and April 2019.

\section{Study population}

The study sample $(\mathrm{n}=493)$ was selected randomly. The sampling process took place at the Red Sea Mall, the Al Salaam Mall, and King Abdulaziz University Hospital.

The inclusion criteria were as follows: caregivers of children aged 0-10 years, having managed at least one pediatric fever episode with paracetamol or ibuprofen, including parents, baby sitters, and grandparents 
aged 18-65 years; English or Arabic speakers; Saudi and non-Saudi caregivers; and willing to participate in the study.

\section{Data collection}

Data collection was performed by seven 6th-year medical students, who were trained how to use the survey instrument before conducting the interviews with the participants. The study's aims and objectives were explained to the participants before enrollment in the study.

\section{Survey instrument}

An interview questionnaire that comprised 40 questions divided into four sections was used in the study. The first section inquired about the demographic data of the caregiver and the child. The second section consisted of seven questions to evaluate the caregiver's knowledge on the use of paracetamol and ibuprofen. The third part explored the caregiver's attitude regarding paracetamol and ibuprofen use. Finally, the fourth section explored the caregiver's practices regarding paracetamol and ibuprofen use. English and Arabic versions of the questionnaire were prepared and reviewed by a bilingual expert. A pilot survey was also conducted on 25 randomly selected individuals to ensure the questionnaire's reliability and internal validity. Additionally, the questionnaire was reviewed by two pharmacologists to assess its reliability.

\section{Data analysis}

Data cleaning and data analysis were performed using Statistical Package for Social Sciences (SPSS) version 21.0 (IBM Corp., Armonk, NY, USA). Frequency and percentages were used for the descriptive analysis. The cutoff point of the knowledge score was set at 5/7. Participants with scores below 5 were considered to have poor knowledge, whereas those with scores equal to or above 5 were considered to have good knowledge of the topic. Pearson's chi-squared test was used to analyze the strength of the association between demographic data and the caregivers' knowledge level. $\mathrm{P}<.05$ was considered statistically significant.

\section{Results}

\section{Demographic characteristics of the study population}

The total number of caregivers involved in the study was 493 . As summarized in Table $1,26.2 \%, 42.6 \%$, $29.2 \%$, and $2 \%$ of the participants aged $18-29,30-39,40-49$, and $>60$ years old, respectively, were included. Most participants were female (75.5\%) and citizens of Saudi Arabia (80.5\%). Regarding education, most participants had a bachelor's degree (75.5\%). Regarding family status, 30.8\% had three or more children, whereas the remaining participants had either one or two children. The participant employment status was as follows: $47.7 \%$ were full-time employees, $40.4 \%$ were unemployed, and $12 \%$ had a part-time job. 


\section{Cureus}

\begin{tabular}{|c|c|c|c|}
\hline & & Frequency & Percentage (\%) \\
\hline \multirow{4}{*}{ Age } & $18-29$ & 129 & 26.2 \\
\hline & $30-39$ & 210 & 42.6 \\
\hline & $40-59$ & 144 & 29.2 \\
\hline & $>60$ & 10 & 2 \\
\hline \multirow{2}{*}{ Sex } & Male & 121 & 24.5 \\
\hline & Female & 372 & 75.5 \\
\hline \multirow{2}{*}{ Nationality } & Saudi & 397 & 80.5 \\
\hline & Non-Saudi & 96 & 19.5 \\
\hline \multirow{4}{*}{ Education level } & Elementary & 4 & 0.8 \\
\hline & Intermediate & 17 & 3.4 \\
\hline & Secondary & 95 & 19.3 \\
\hline & University & 377 & 76.5 \\
\hline \multirow{3}{*}{ Employment status } & Not working & 199 & 40.4 \\
\hline & Part time & 59 & 12 \\
\hline & Full time & 235 & 47.7 \\
\hline \multirow{4}{*}{ Number of children } & 1 & 120 & 24.3 \\
\hline & 2 & 126 & 25.6 \\
\hline & 3 & 95 & 19.3 \\
\hline & $>3$ & 152 & 30.8 \\
\hline
\end{tabular}

TABLE 1: Caregivers' characteristics $(n=493)$

\section{Caregivers' knowledge of antipyretic administration}

Table 2 shows the items used to measure the knowledge score of the caregivers on the use of paracetamol and ibuprofen as antipyretic drugs; $40.4 \%$ of the caregivers indicated that the age of the child was the main factor influencing the dosage of paracetamol and ibuprofen administered, whereas $32 \%$ reported the weight of the child as the main factor. 


\section{Cureus}

\begin{tabular}{|c|c|c|c|}
\hline \multicolumn{2}{|l|}{ Questions } & Frequency & $\begin{array}{l}\text { Percentage } \\
\text { (\%) }\end{array}$ \\
\hline \multirow{3}{*}{ Do you know the factors influencing the paracetamol/ ibuprofen dose? } & Child's weight (correct answer) & 158 & 32 \\
\hline & Child's age & 199 & 40.4 \\
\hline & Wlness severity (body temperature in ${ }^{\circ} \mathrm{C}$ ) & 136 & 27.6 \\
\hline \multirow{4}{*}{ What is the recommended dose for paracetamol? } & $<10-15 \mathrm{mg} / \mathrm{kg} /$ dose & 139 & 28.2 \\
\hline & 10-15 mg/kg/dose (correct answer) & 159 & 32.3 \\
\hline & $>10-15$ mg/kg/dose & 14 & 2.8 \\
\hline & Not sure & 181 & 36.7 \\
\hline \multirow{4}{*}{ How often do you administer paracetamol? } & Every 4 hours & 66 & 13.4 \\
\hline & Every 6 hours (correct answer) & 149 & 30.2 \\
\hline & Every 8 hours & 160 & 32.5 \\
\hline & $\begin{array}{l}\text { Whenever the body temperature exceeds } \\
37^{\circ} \mathrm{C}\end{array}$ & 118 & 23.9 \\
\hline \multirow{6}{*}{$\begin{array}{l}\text { What is the maximum daily frequency of paracetamol administration } \\
\text { (times)? }\end{array}$} & 1 & 21 & 4.3 \\
\hline & 2 & 58 & 11.8 \\
\hline & 3 & 187 & 37.9 \\
\hline & 4 & 164 & 33.3 \\
\hline & 5 (correct answer) & 18 & 3.7 \\
\hline & 6 & 45 & 9.1 \\
\hline \multirow{4}{*}{ What is the recommended dose for ibuprofen? } & $<4-10 \mathrm{mg} / \mathrm{kg} / \mathrm{dose}$ & 49 & 9.9 \\
\hline & 4-10 mg/kg/dose (correct answer) & 155 & 31.4 \\
\hline & $>4-10 \mathrm{mg} / \mathrm{kg} / \mathrm{dose}$ & 35 & 7.1 \\
\hline & Not sure & 254 & 51.5 \\
\hline \multirow{4}{*}{ How often do you administer ibuprofen? } & Every 4 hours & 46 & 9.3 \\
\hline & Every 6 hours & 107 & 21.7 \\
\hline & Every 8 hours (correct answer) & 199 & 40.4 \\
\hline & $\begin{array}{l}\text { Whenever the body temperature exceeds } \\
37^{\circ} \mathrm{C}\end{array}$ & 141 & 28.6 \\
\hline \multirow{6}{*}{$\begin{array}{l}\text { What is the maximum daily frequency of ibuprofen administration } \\
\text { (times)? }\end{array}$} & 1 & 26 & 5.3 \\
\hline & 2 & 126 & 25.6 \\
\hline & 3 (correct answer) & 195 & 39.6 \\
\hline & 4 & 105 & 21.3 \\
\hline & 5 & 11 & 2.2 \\
\hline & 6 & 30 & 6.1 \\
\hline
\end{tabular}

TABLE 2: Caregivers' knowledge of antipyretic administration ( $n=493)$

Of all participants, 32.3\% were aware of the recommended dosage of paracetamol (10 to $15 \mathrm{mg} / \mathrm{kg}$ ), whereas $36.7 \%$ were not sure. Of the total number of caregivers, $30.2 \%$ administered paracetamol every six hours compared to $32.5 \%$ who administered it every eight hours. A staggering $23.9 \%$ administered paracetamol to their child whenever the child's body temperature exceeded $37^{\circ} \mathrm{C}$. As for the frequency of the daily intake of 


\section{Cureus}

paracetamol, only $3.7 \%$ specified a daily maximum of five times, compared to $37.9 \%$ reporting a daily maximum of three times and $33.3 \%$ of four times.

Of all caregivers using ibuprofen, 31.4\% reported administering $4-10 \mathrm{mg} / \mathrm{kg}$ of ibuprofen as recommended, whereas $51.5 \%$ were not sure about the dosage. Regarding the time interval of administration, $40.4 \%$ administered ibuprofen every eight hours, $21.7 \%$ every six hours, and $9.3 \%$ every four hours; $28.6 \%$ administered it whenever the child's body temperature exceeded $37^{\circ} \mathrm{C}$. As for the frequency of ibuprofen intake, $39.6 \%$ specified a daily maximum of three times, compared to $25.6 \%$ reporting a maximum of two times and $21.3 \%$ of four times.

Only $32 \%$ of the participants answered correctly when questioned about the factors that influence paracetamol and ibuprofen dosage (Table 3). The results about the dosage and frequency pertaining to paracetamol and ibuprofen usage were as follows: $30.2 \%$ answered correctly regarding the frequency of administering paracetamol, whereas $40.4 \%$ answered correctly regarding the frequency of administering ibuprofen. Only $3.7 \%$ answered correctly regarding the maximum daily frequency of paracetamol compared to the $39.6 \%$ who answered correctly regarding ibuprofen frequency.

\begin{tabular}{|c|c|c|c|c|}
\hline \multirow{2}{*}{ Knowledge items } & \multicolumn{2}{|l|}{ False } & \multicolumn{2}{|l|}{ True } \\
\hline & Frequency & Percentage (\%) & Frequency & Percentage (\%) \\
\hline Factors influencing paracetamol/ibuprofen dose & 335 & 68 & 158 & 32 \\
\hline Recommended dose for paracetamol & 334 & 67.7 & 159 & 32.3 \\
\hline How often is paracetamol administered? & 344 & 69.8 & 149 & 30.2 \\
\hline Maximum daily frequency of paracetamol & 475 & 96.3 & 18 & 3.7 \\
\hline Recommended dose for ibuprofen & 338 & 68.6 & 155 & 31.4 \\
\hline How often is ibuprofen administered? & 294 & 59.6 & 199 & 40.4 \\
\hline Maximum daily frequency of ibuprofen & 298 & 60.4 & 195 & 39.6 \\
\hline \multicolumn{5}{|l|}{ Overall knowledge score (Mean [SD], 2.1 [1.34]) } \\
\hline Poor knowledge (<5 score) & $478(97 \%)$ & & & \\
\hline Good knowledge ( $\geq 5$ score) & $15(3.0 \%)$ & & & \\
\hline
\end{tabular}

TABLE 3: Caregivers' knowledge score $(n=493)$

Therefore, the mean for the overall knowledge score was 2.09 , with only $3 \%$ of the participants presenting decent knowledge and $97 \%$ demonstrating poor knowledge of the factors influencing paracetamol and ibuprofen dosage.

\section{Caregivers' awareness of antipyretic administration}

The caregivers' awareness level is presented in Table 4 . Approximately $71.2 \%$ of the caregivers stated that they obtained information on paracetamol and ibuprofen from doctors and $20.3 \%$ from pharmacists. Of all caregivers, $25.8 \%$ stated that they were aware of liver damage as a side effect of paracetamol. Regarding the route/form used to administer paracetamol and ibuprofen, $52.1 \%$ of caregivers used syrups, whereas $38.1 \%$ of caregivers used a combination of both syrups and suppositories. 


\section{Cureus}

\begin{tabular}{|c|c|c|c|}
\hline & & Frequency & $\begin{array}{l}\text { Percentage } \\
\text { (\%) }\end{array}$ \\
\hline \multirow{5}{*}{ From where do you get information regarding paracetamol and ibuprofen? } & Doctor & 351 & 71.2 \\
\hline & Pharmacist & 100 & 20.3 \\
\hline & Media & 12 & 2.4 \\
\hline & Other parents & 22 & 4.5 \\
\hline & Other & 8 & 1.6 \\
\hline \multirow{5}{*}{ Are you aware of paracetamol's side effects? } & Liver damage & 127 & 25.8 \\
\hline & Kidney damage & 99 & 20.1 \\
\hline & Allergy & 50 & 10.1 \\
\hline & Effect on stomach & 24 & 4.9 \\
\hline & Other & 193 & 39.1 \\
\hline \multirow{4}{*}{ What is the form of paracetamol/ibuprofen that you use? } & Syrups & 257 & 52.1 \\
\hline & Suppositories & 41 & 8.3 \\
\hline & Injection & 7 & 1.4 \\
\hline & $\begin{array}{l}\text { Syrups and suppositories } \\
\text { combined }\end{array}$ & 188 & 38.1 \\
\hline \multirow{2}{*}{$\begin{array}{l}\text { Do you think it is fine to give paracetamol/ibuprofen to your child without a } \\
\text { prescription? }\end{array}$} & No & 146 & 29.6 \\
\hline & Yes & 347 & 70.4 \\
\hline \multirow{2}{*}{ Do you think it is fine to give paracetamol/ibuprofen together? } & Yes & 74 & 15 \\
\hline & No & 419 & 85 \\
\hline
\end{tabular}

TABLE 4: Caregivers' awareness on antipyretic administration $(n=493)$

Regarding the caregivers' awareness about administering paracetamol/ibuprofen without a prescription, $70.4 \%$ stated that a prescription was not needed and only $29.6 \%$ stated that it was warranted. Approximately $85 \%$ of the caregivers thought that paracetamol and ibuprofen should not be administered together, whereas only $15 \%$ thought that they can be given together.

\section{Caregivers' practices regarding antipyretic administration}

Of the caregivers, $51.7 \%$ claimed that they administered antipyretics at a body temperature of $38-38.5^{\circ} \mathrm{C}$, whereas $32.9 \%$ reported that they administered antipyretics when the temperature exceeded $38.5^{\circ} \mathrm{C}$. Only $14.2 \%$ and $1.2 \%$ administered antipyretics for temperatures greater than $39^{\circ} \mathrm{C}$ and $40^{\circ} \mathrm{C}$, respectively. Regarding the instruments or devices used to measure body temperature, $74.6 \%$ used a thermometer, $23.1 \%$ judged by touching the forehead, whereas less than $2.2 \%$ judged by touching the lips or used other techniques to estimate the temperature.

Regarding the caregivers' practices (Table 5), most participants agreed on paracetamol being the most common antipyretic administered to children (54\%), $18.5 \%$ reported ibuprofen as the most common antipyretic, and $14.8 \%$ stated that both were equally common; only $12.8 \%$ thought that there were other more common antipyretics. A total of $35.9 \%$ of caregivers administered paracetamol/ibuprofen for reasons other than fever and $90.7 \%$ measured the child's body temperature using a thermometer before administering antipyretics. The majority (85.2\%) read the medication leaflet beforehand, whereas $14.8 \% \mathrm{did}$ not. Measuring spoons and syringes were the most commonly used measuring devices when administering paracetamol/ibuprofen with frequencies of $42.8 \%$ and $43.8 \%$, respectively. 


\section{Cureus}

\begin{tabular}{|c|c|c|c|}
\hline & & Frequency & $\begin{array}{l}\text { Percentage } \\
\text { (\%) }\end{array}$ \\
\hline \multirow{4}{*}{ At which body temperature do you administer an antipyretic? } & $38-38.5$ & 255 & 51.7 \\
\hline & $>38.5$ & 162 & 32.9 \\
\hline & $>39$ & 70 & 14.2 \\
\hline & $>40$ & 6 & 1.2 \\
\hline \multirow{4}{*}{ How do you measure the child's body temperature? } & Using a thermometer & 368 & 74.6 \\
\hline & $\begin{array}{l}\text { By touching the } \\
\text { forehead }\end{array}$ & 114 & 23.1 \\
\hline & By touching the lips & 8 & 1.6 \\
\hline & Other & 3 & 0.6 \\
\hline \multirow{4}{*}{ The most common antipyretic that you administer to your child } & Paracetamol & 266 & 54 \\
\hline & Ibuprofen & 91 & 18.5 \\
\hline & Both & 73 & 14.8 \\
\hline & Other & 63 & 12.8 \\
\hline \multirow{2}{*}{ Do you administer paracetamol/ibuprofen for reasons other than fever? } & Yes & 177 & 35.9 \\
\hline & No & 316 & 64.1 \\
\hline \multirow{2}{*}{$\begin{array}{l}\text { Do you measure the child's body temperature using a thermometer before administering } \\
\text { antipyretics? }\end{array}$} & Yes & 447 & 90.7 \\
\hline & No & 46 & 9.3 \\
\hline \multirow{2}{*}{ Do you read the medication leaflet? } & Yes & 420 & 85.2 \\
\hline & No & 73 & 14.8 \\
\hline \multirow{4}{*}{ What do you use as a measuring device when you administer paracetamol/ibuprofen? } & Teaspoon & 41 & 8.3 \\
\hline & Measuring spoon & 211 & 42.8 \\
\hline & Measuring syringe & 216 & 43.8 \\
\hline & Other & 25 & 5.1 \\
\hline
\end{tabular}

TABLE 5: Caregiver practices in antipyretic administration $(n=493)$

Factors affecting caregivers' level of knowledge

Caregivers aged 30-39 years had a good level of knowledge compared to those >60 years old (Table 6). However, the difference was not significant $(\mathrm{P}=.803)$. 


\section{Cureus}

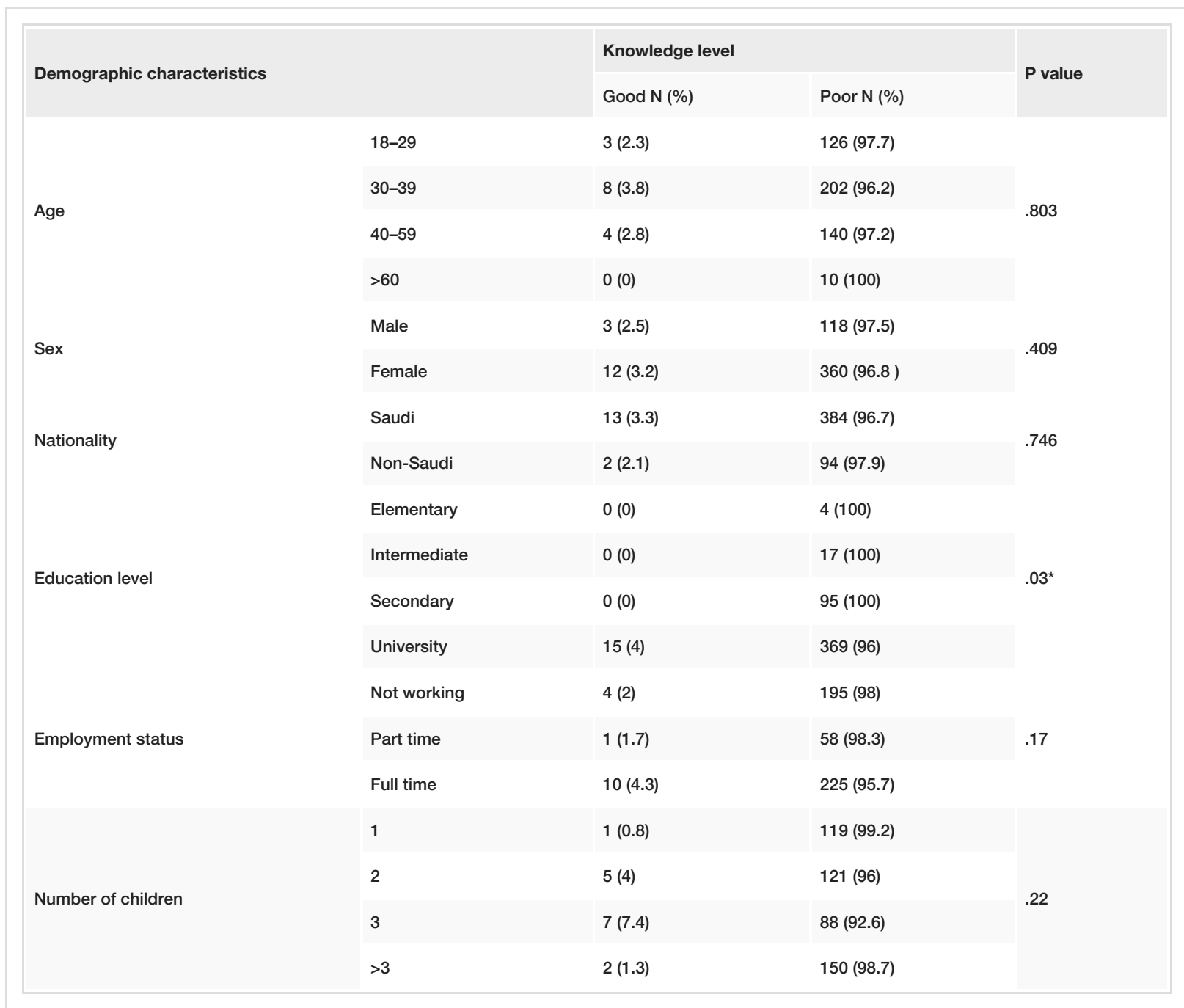

TABLE 6: Demographic factors affecting caregivers' knowledge $(n=493)$

Similarly, sex and nationality did not affect the level of knowledge ( $\mathrm{P}=.409$ and $\mathrm{P}=.746$, respectively). However, female Saudi caregivers showed a slightly higher knowledge level compared with peer controls.

Conversely, caregivers with a university education level showed a significantly better knowledge level regarding antipyretics than the other groups $(\mathrm{P}=.03)$.

Finally, the employment status and number of offspring were not found to be statistically significant factors affecting the knowledge level $(\mathrm{P}=.17, \mathrm{P}=.22$, respectively). However, full-time caregivers and those with three children showed a slightly better level of knowledge.

\section{Discussion}

This study evaluated caregivers' knowledge, awareness, and practice of the dosage, side effects, and complications of over-the-counter antipyretic drug administration to the pediatric age group in Jeddah, Saudi Arabia.

Regarding fever measurement, our results indicate that a large number of parents use a thermometer as the primary method, whereas other techniques such as touching the forehead or the lips were less commonly used. These findings are similar to those from other studies $[1,15]$. Surprisingly, most parents in these studies measured fever by touching the forehead, partly due to the poor socio-economic condition in those countries, [7,15], which poses significant difficulties for parents in purchasing thermometers.

Herein, we found that paracetamol was the most common antipyretic that parents used to treat fever which was corroborated by research conducted in other countries $[1,2,16,17]$. Moreover, since many parents pass on knowledge/inform their child's caregiver about paracetamol use for fever, we believe that they do not provide adequate information and correct knowledge about dosage or how/when to administer it, explaining 
why $97 \%$ of caregivers in our study presented an inadequate knowledge score. Only $32.2 \%$ of caregivers were only aware of the correct dose of $10 \mathrm{mg} / \mathrm{kg} / \mathrm{day}$ when questioned about paracetamol dosage. Conversely, $58.3 \%$ responded correctly on this topic in another study [12]. This variation may be attributed to a lack of information on the daily prescription dose of paracetamol. These findings align with those from other studies conducted in Sri Lanka, Nigeria, and Australia [7-9], which highlighted the need for parental education regarding fever medication dosage and administration.

This low level of knowledge about the dosage and administration of antipyretics may influence improper drug intake, which can cause serious side effects. Furthermore, children of working mothers being taken care of by babysitters are at a higher risk of antipyretic overdosing, as found in another study [7].

Here, we also found that most parents received information from doctors and pharmacists and read the medication leaflet beforehand. However, these affirmations were not consistent with the knowledge scores since most participants achieved a low score in this domain. Similar paradoxical results have been found in another study [7]. This may indicate that although parents may read the drug information leaflet before administering medications to their children, they may have a limited understanding of the information read. Hence, this may result in a positive cautious behavior of reading the leaflet, which unfortunately does not necessarily mean correct administration, due to a lack of understanding. Consequently, this aspect is worthy of further investigation.

Walsh et al. [9] mentioned that health professionals play an important role in providing parents with appropriate strategies regarding fever management, which in turn requires the provision of evidence-based education to health professionals. However, our study found that most parents (70.4\%) administered antipyretics without a prescription. Conversely, $46.8 \%$ of parents in another study claimed to administer antipyretics based on a doctor's prescription [15]. This disparity could be explained as parents in our population underestimating the damaging effects of paracetamol and ibuprofen. Therefore, they tend to administer paracetamol based on their experience.

The caregivers' educational status had a significant effect on the knowledge and forms used when administering antipyretics, a finding that corroborates with those of other studies including different populations [17-20]. Concomitantly, these results may indicate that caregivers with higher education may better comprehend the information on a drug leaflet, thus improving their knowledge of administration. Future research is warranted to elucidate these effects.

Regarding caregivers' awareness of the side effects associated with antipyretics, $56 \%$ of the participants specified certain side effects of the drugs, whereas the rest believed that they caused none or unknown effects; $25.8 \%, 20.1 \%$, and $10.1 \%$ of caregivers believed that the drugs caused liver toxicity, kidney damage, and allergies, respectively. We believe that this is a small number of the population who were conscious of the side effects of both drugs, which may warrant future studies and awareness campaigns. Further, syrups were the most preferred form used to administer antipyretics (52.1\%). This finding is similar to that of another survey [15], which showed that parents favored oral drugs (51.2\%) over suppositories. This might be because the oral route is convenient for the administration of medication in children.

We found that the number of children the parents/caregivers did not influence their knowledge score. These results are in contrast with those from a study conducted in Denmark [2] showing that parents who have more than one child were better prepared, had less fear, and greater knowledge when using antipyretics as a result of previous experience.

Finally, this survey assessed parents' responses related to the body temperature at which they administered antipyretics. More than $50 \%$ claimed they would start at the lowest margin, which was $38^{\circ} \mathrm{C}$. This finding is similar to that from other studies $[1,9]$ in which parents defined fever as any temperature above $38^{\circ} \mathrm{C}$ and would, therefore, start medication at this level.

\section{Strengths and limitations}

One of the main strengths of the study is the large sample size, which strongly contributes to the generalizability of the results. The manual data input used for each parent to prevent misunderstanding of the survey questions is another strength, contributing to the results' reliability. Another strength is the random selection of participants at malls and clinics. Moreover, we ensured that the survey was available in both Arabic and English to ensure that both Saudi and non-Saudi caregivers could be interviewed, contributing to the variability of participants included. However, one of the limitations of the study is that the collected data concerned residents of the same city, Jeddah; results from other territories may show different knowledge, practice, and attitude scores. Hence, the results may not be representative of the entire Saudi Arabian population. As such, this indicated the necessity for further surveys in other cities. Additionally, since this study was developed based on previous research on the same subject, it was discovered that there is a limited number of studies in Jeddah and worldwide, on the side effects of antipyretics as well as the awareness of correct dosages and general knowledge about these drugs. 


\section{Cureus}

\section{Conclusions}

This study highlights the need for parental education on the use, dosage, and side effects of antipyretic drugs. Hence, this work demonstrated that most parents were unaware of the severity of the side effects of paracetamol and ibuprofen. Furthermore, more than half of the parents did not know the correct dosage of both drugs, indicating a lack of knowledge regarding the use of antipyretics for fever management. It also showed that the caregivers who knew the actual side effects and dosage had a bachelor's degree, which shows that educational background plays a significant role in parental knowledge of fever management. The majority of parents used syrups as the form of administering antipyretics. There were no significant differences in knowledge scores between Saudis and non-Saudis. Additionally, the researchers felt that parents often panic when treating their child due to the fear of the harmful effect of fever, which may lead to unintentional overdoses. It found that the number of offspring that parents have do not influence parental knowledge about antipyretics. Our findings thus indicate a need for educational programs to provide parents with proper education on fever and fever management.

\section{Appendices}

\begin{tabular}{|c|c|c|c|c|c|c|}
\hline 1 & Age of the caregiver: & $18-29$ & $30-39$ & 40-59 & \multicolumn{2}{|l|}{360} \\
\hline 2 & Gender of the caregiver: & Male & \multicolumn{4}{|l|}{ Female } \\
\hline 3 & Nationality: & Saudi & \multicolumn{2}{|l|}{ Non-Saudi } & & \\
\hline 4 & Education level of the caregiver: & Non educated & Elementary & Intermediate & Secondary & University \\
\hline 5 & Employment status: & Not working & Part time & Full time & & \\
\hline 6 & Number of children & 1 & 2 & 3 & \multicolumn{2}{|l|}{$>3$} \\
\hline 7 & Child's age (the sick one): & $0-3$ months & 4-36 months & >36 months & & \\
\hline
\end{tabular}

\section{TABLE 7: Part 1. Demographic Data of caregiver}

8 At which temperature you give antipyretic?

9 How do you measure child's temperature?

10 From where do you get the information regarding paracetamol and ibuprofen dose?

11 Are you aware of paracetamol side effects?

12 Do you know the factors influencing paracetamol/ibuprofen dose?

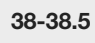

By thermometer forehead

Doctor

Liver

damage

Child's

weight

$>38.5$

Pharmacist

Kidney damage

Child's age
By touching the By touching

the lip

Media

Allergy

\section{TABLE 8: Part II: Knowledge of caregivers regarding paracetamol and ibuprofen}

13 What is the form of paracetamol/ ibuprofen you use?

Do you think it is ok to give paracetamol/ ibuprofen to your child without

14 prescription?

15 Do you think it is ok to give paracetamol/ ibuprofen together?
Syrups Suppositories Injection

Syrups and suppositories combined

Yes $\quad$ No

TABLE 9: Part III: Attitude of caregivers regarding paracetamol and ibuprofen 


\section{Cureus}

\begin{tabular}{|c|c|c|c|c|c|}
\hline 16 & Most common antipyretic you give your child? & Paracetamol & Ibuprofen & Both & Other \\
\hline 17 & What is the recommended dose for paracetamol? & $\begin{array}{l}<10-15 \\
\mathrm{mg} / \mathrm{kg} / \text { dose }\end{array}$ & $\begin{array}{c}10-15 \\
\mathrm{mg} / \mathrm{kg} / \mathrm{dose}\end{array}$ & $\begin{array}{l}<10-15 \\
\mathrm{mg} / \mathrm{kg} / \mathrm{dose}\end{array}$ & Not sure \\
\hline 18 & How often do you give paracetamol? & Every $4 \mathrm{hr}$ & Every $6 \mathrm{hr}$ & Every $8 \mathrm{hr}$ & $\begin{array}{l}\text { Whenever temperature } \\
\text { exceed } 37\end{array}$ \\
\hline 19 & What is the maximum daily frequency of paracetamol? & 2 & 3 & 4 & 5 \\
\hline 20 & What is the recommended dose for ibuprofen? & $\begin{array}{l}<4-10 \\
\mathrm{mg} / \mathrm{kg} / \text { dose }\end{array}$ & $\begin{array}{l}4-10 \\
\mathrm{mg} / \mathrm{kg} / \mathrm{dose}\end{array}$ & $\begin{array}{l}<4- \\
10 \mathrm{mg} / \mathrm{kg} / \mathrm{dose}\end{array}$ & Not sure \\
\hline 21 & How often do you give ibuprofen? & Every $4 \mathrm{hr}$ & Every $6 \mathrm{hr}$ & Every $8 \mathrm{hr}$ & $\begin{array}{l}\text { Whenever temperature } \\
\text { exceed } 37\end{array}$ \\
\hline 22 & What is the maximum daily frequency of ibuprofen? & 2 & 3 & 4 & 6 \\
\hline 23 & $\begin{array}{l}\text { Do you give paracetamol/ ibuprofen for other reasons } \\
\text { (OTHER THAN FEVER)? }\end{array}$ & Yes & No & & \\
\hline 24 & $\begin{array}{l}\text { Do you measure child's temperature by thermometer before } \\
\text { giving the antipyretic? }\end{array}$ & Yes & No & & \\
\hline 25 & Do you have the habit to read the medication leaflet? & Yes & No & & \\
\hline 26 & $\begin{array}{l}\text { What do you use as a measuring device when you give } \\
\text { paracetamol/ ibuprofen? }\end{array}$ & Tea spoon & $\begin{array}{l}\text { Measuring } \\
\text { spoon }\end{array}$ & $\begin{array}{l}\text { Measuring } \\
\text { syringe }\end{array}$ & Other \\
\hline
\end{tabular}

TABLE 10: Part IV: Practice of caregivers regarding paracetamol and ibuprofen

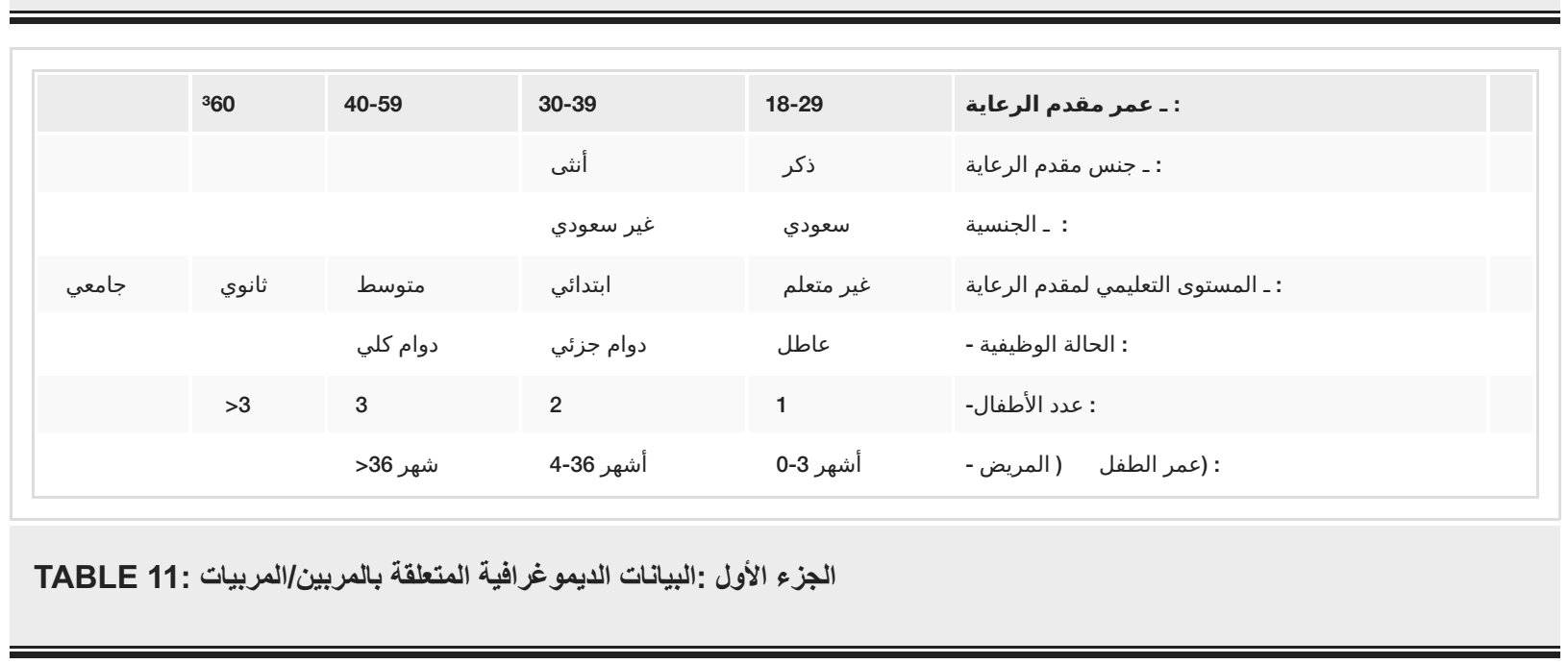




\section{Cureus}

8

عند أي درجة حرارة ينم إعطاء مخفض الحرارة؟-

/38-38.5

أكثر من38,5/

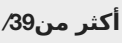

أكثر/

كيف تقيسر/ 9

عن طريق الثيرمومتر(جهاز)

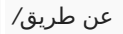
(لقياس الحرارة

لمس الجبين

من أين تحصل/ين على المعلومات المتعلقة بجرعة- 10

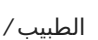

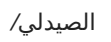

وسائل التواصل/ إعلاعم

(الباراسيتامول والأيبوبروفين) بجرعة المنعة

هل أنت مدرك/ة بالأعراض الجانبية للباراسيتامول؟- 11

مضرة الكبد/

مضرة الكلية/ - مضا

الاجتماعي/الإعلام

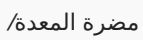

من 40

هل أنت مدرك/ة بالعوامل المؤثرة في اختيار جرعات- 12

(الأيبوبروفين والباراسيتامول) إنتر جرعات

وزن الطفل/

عمر الطفل/

شدة المرض(بالاعتماد على/ (درجة الحرارة

(درجة الحرارة

TABLE 12: الجزء الثاني:مدى معرفة مقدمي الرعاية عن أدوية الباراسيتامول (بانادول)وأيبوبروفين:

\begin{tabular}{|c|c|c|c|c|c|}
\hline \multirow[t]{3}{*}{ 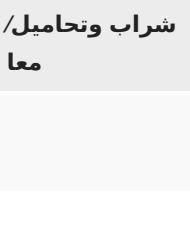 } & عن طريق/ الحقن & تحاميل/ & شراب/ & ما هي الشكل الدوائي (الباراسيتامول/الأيبوبروفين) التي تستخدمها؟ - & 13 \\
\hline & & I & نعم/ & هل تعتقد/ين أنه من الصحيح إعطاء الطفل (أيبوبروفين/باراسيتامول) بدون إستشارة- & 14 \\
\hline & & N & نعم/ & هل تعتقد/ين أنه من الصحيح إعطاء (الأيبوبروفين والباراسيتامول معا)؟- & 15 \\
\hline
\end{tabular}

TABLE 13: الجزء الثالث:توجه مقدمي الرعاية فيما يتعلق بالباراسيتامول والأيبوبروفين:

\begin{tabular}{|c|c|c|c|c|c|c|}
\hline & 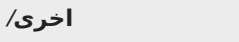 & 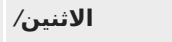 & ايبوبروفين/ ا & باراسيتامول/ & ما هو أكثر خافض حرارة تستخدمه لطلغلك؟؟- & 16 \\
\hline & 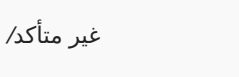 & أكثر من · ا-10 - أ ميليغرام & 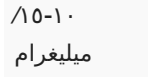 & أقل من · ا-10 إم ميليغرام & ما هي الجرعة الموصى بها للباراسيتامول؟- & 17 \\
\hline & الحرارة عن الزما تزيد درجة/ & 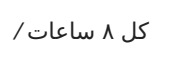 & كل 7 ساعات/ & كل ع ساعات/ & كم عدد المرات التي يتم فيها إعطاء الباراسيتامول؟- & 18 \\
\hline 6 & $5 /$ & $4 /$ & $3 /$ & $1 /$ & ما هو الحد الآقصى اليومي لتكرار اعطاء الباراسيتامول؟- & 19 \\
\hline & غير متأكد/ & أكثر من ع-·· ميليغرام & ميليغرام & أقل منع-- أ ميليغرام & ما هي الجرعة الموصى بها للآيبوبروفين؟- & 20 \\
\hline & 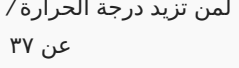 & كل ^ شاعات/ & كل 7 ساعات/ & كل ع ساعات/ & كم عدد المرات التي يتم فيها إعطاء الآيبوبروفين؟-- & 21 \\
\hline 6 & $5 /$ & $4 /$ & $3 /$ & $2 /$ & ما هو الحد الأقصى اليومي لتكرار اعطاء الأيبوبروفين؟- & 22 \\
\hline & & & A & نعم/ & هل تقوم بإعطاء الباراسيتامول-أيبوبروفين لأسباب أخرى(لغير- & 23 \\
\hline & & & s & نعم/ & هل تقوم بقياس درجة حرارة الطفل قبل اعطائه خافض الحرارة؟- & 24 \\
\hline & & & I & نعم/ & هل تحرص عادة بقراءة المنشور المرفق بالدواء؟- & 25 \\
\hline & 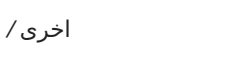 & ابرة قياسية/ اسية & ق مياسية & 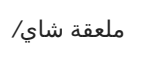 & 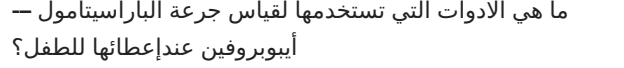 & 26 \\
\hline
\end{tabular}

TABLE 14: الجزء الرابع : ممارسات مقدمي الرعاية المتعلقة باعطاء (الباراسيتامول والآيبوبروفين):

\section{Additional Information \\ Disclosures}

Human subjects: Consent was obtained or waived by all participants in this study. Biomedical Research 
Ethics Committee at King Abdulaziz University issued approval issued approval (Reference No. 75-20). This study was approved by the Biomedical Research Ethics Committee at King Abdulaziz University (Reference No. 75-20). Participation in the study was voluntary and consent was taken from all participants after they were notified about the study objectives and confidentiality of the responses. Animal subjects: All authors have confirmed that this study did not involve animal subjects or tissue. Conflicts of interest: In compliance with the ICMJE uniform disclosure form, all authors declare the following: Payment/services info: All authors have declared that no financial support was received from any organization for the submitted work. Financial relationships: All authors have declared that they have no financial relationships at present or within the previous three years with any organizations that might have an interest in the submitted work. Other relationships: All authors have declared that there are no other relationships or activities that could appear to have influenced the submitted work.

\section{References}

1. Rkain M, Rkain I, Safi M, Kabiri M, Ahid S, Benjelloun B: Knowledge and management of fever among Moroccan parents. East Mediterr Health J. 2014, 20: 10.26719/2014.20.6.397

2. Sahm LJ, Kelly M, McCarthy S, O'Sullivan R, Shiely F, Rømsing J: Knowledge, attitudes and beliefs of parents regarding fever in children: a Danish interview study. Acta Paediatr. 2016, 105:69-73.

3. Teagle AR, Powell CV: Is fever phobia driving inappropriate use of antipyretics? . Arch Dis Child. 2014, 99:701-702. 10.1136/archdischild-2013-305853

4. Crocetti M, Sabath B, Cranmer L, Gubser S, Dooley D: Knowledge and management of fever among Latino parents. Clin Pediatr. 2009, 48:183-189. 10.1177/0009922808324949

5. Walsh A, Edwards H: Management of childhood fever by parents: literature review . J Adv Nurs. 2006, 54:217227.

6. De S, Tong A, Isaacs D, Craig JC: Parental perspectives on evaluation and management of fever in young infants: an interview study. Arch Dis Child. 2014, 99:717-723. 10.1136/archdischild-2013-305736

7. Ramanayake R, Jayasinghe L, De Silva A, Wijesinghe W, Kanaganayagam N: Knowledge and practices of paracetamol administration among caregivers of pediatric age group patients. J Family Med Prim Care. 2012, 1:30. 10.4103\%2F2249-4863.94448

8. Obu HA, Chinawa JM, Ubesie AC, Eke CB, Ndu IK: Paracetamol use (and/or misuse) in children in Enugu, South-East, Nigeria. BMC Pediatr. 2012, 12:103. 10.1186/1471-2431-12-103

9. Walsh A, Edwards H, Fraser J: Over-the-counter medication use for childhood fever: a cross-sectional study of Australian parents. J Paediatr Child Health. 2007, 43:601-606. 10.1111/j.1440-1754.2007.01161.x

10. Allegaert K, Naulaers G, Vanhaesebrouck S, Anderson BJ: The paracetamol concentration-effect relation in neonates. Pediatr Anesth. 2013, 23:45-50. 10.1111/pan.12076

11. Hixson R, Franke U, Mittal R, Hamilton M: Parental calculation of pediatric paracetamol dose: a randomized trial comparing the Parental Analgesia Slide with product information leaflets. Pediatr Anesth. 2010, 20:612-619.

12. Grézy-Chabardès C, Fournier J-P, Dupouy J, Poutrain J-C, Oustric S: Patients’ knowledge about analgesicantipyretic medications purchased in community pharmacies: a descriptive study. J Pain Palliat Care Pharmacother. 2015, 29:334-340. 10.3109/15360288.2015.1082007

13. Ciampa PJ, White RO, Perrin EM, et al.: The association of acculturation and health literacy, numeracy and health-related skills in Spanish-speaking caregivers of young children. J Immigr Minor Health. 2013, 15:492498. 10.1007/s10903-012-9613-7

14. Poonai N, Bhullar G, Lin K, et al.: Oral administration of morphine versus ibuprofen to manage postfracture pain in children: a randomized trial. CMAJ. 2014, 186:1358-1363. 10.1503/cmaj.140907

15. Sa'ed HZ, Al-Jabi SW, Sweileh WM, et al.: Beliefs and practices regarding childhood fever among parents: a cross-sectional study from Palestine. BMC Pediatr. 2013, 13:66. 10.1186/1471-2431-13-66

16. Blumenthal I: What parents think of fever. Fam Pract. 1998, 15:513-518. 10.1093/fampra/15.6.513

17. Taveras EM, Durousseau S, Flores G: Parents' beliefs and practices regarding childhood fever: a study of a multiethnic and socioeconomically diverse sample of parents. Pediatr Emerg Care. 2004, 20:579-587. 10.1097/01.pec.0000139739.46591.dd

18. Mackowiak PA: Concepts of fever. Arch Intern Med. 1998, 158:1870-1881. 10.1001/archinte.158.17.1870

19. Poirier MP, Collins EP, McGuire E: Fever phobia: a survey of caregivers of children seen in a pediatric emergency department. Clin Pediatr. 2010, 49:530-534. 10.1177/0009922809355312

20. Walsh A, Edwards H, Fraser J: Parents' childhood fever management: community survey and instrument development. J Adv Nurs. 2008, 63:376-388. 